\title{
Heterogeneous Os isotope compositions in the Kalatongke sulfide deposit, NW China: the role of crustal contamination
}

\author{
Jian-Feng Gao • Mei-Fu Zhou • Peter C. Lightfoot • \\ Wenjun Qu
}

Received: 22 November 2010 / Accepted: 25 January 2012/Published online: 12 April 2012

(C) The Author(s) 2012. This article is published with open access at Springerlink.com

\begin{abstract}
Re-Os isotope compositions of mantle-derived magmas are highly sensitive to crustal contamination because the crust and mantle have very different Os isotope compositions. Crustal contamination may trigger $\mathrm{S}$ saturation and thus the formation of magmatic $\mathrm{Ni}-\mathrm{Cu}$-(PGE) sulfide deposits. The 287-Ma Kalatongke norite intrusion of NW China are hosted in carboniferous tuffaceous rocks and contain both disseminated and massive sulfide mineralization. The Re-Os isotope compositions in the intrusion are highly variable. Norite and massive sulfide ores have $\gamma_{\mathrm{Os}}$ values ranging from +59 to +160 and a Re-Os isochron age of $239 \pm 51 \mathrm{Ma}$, whereas disseminated sulfide ores have $\gamma_{\mathrm{Os}}$ values from +117 to +198 and a Re-Os isochron age of $349 \pm 34 \mathrm{Ma}$. The variability of Os isotope compositions can be explained as the emplacement of two distinct magma pulses. Massive sulfide ores and barren norite in the intrusion formed from the same magma pulse, whereas the disseminated sulfide ores
\end{abstract}

Editorial handling: F. Barra

J.-F. Gao • M.-F. Zhou $(\triangle)$

Department of Earth Sciences, The University of Hong Kong,

Hong Kong, China

e-mail: mfzhou@hkucc.hku.hk

J.-F. Gao

e-mail:gao_jianfeng@yahoo.com

P. C. Lightfoot

Vale,

Highway 17 West,

Sudbury, ON P0M 1N0, Canada

e-mail: Peter.Lightfoot@vale.com

W. Qu

National Research Center of Geoanalysis (NRCG),

Chinese Academy of Geological Sciences,

Beijing, China

e-mail: quwenjun03@163.com with more radiogenic Os isotopes formed from another magma pulse which underwent different degrees of crustal contamination. Re-Os isotopes may not be suitable for dating sulfidebearing intrusions that underwent variable degrees of crustal contamination to form magmatic sulfide deposits.

Keywords Re-Os isotopes · Sulfides · Sulfide-bearing intrusions $\cdot$ Crustal contamination · Sulfide segregation

\section{Introduction}

The precise determination of the formation age of magmatic sulfide mineralization is important for understanding the origin of mineral deposits and their host intrusions. The $\mathrm{Re}-\mathrm{Os}$ isotopic system has been used to date magmatic $\mathrm{Ni}-\mathrm{Cu}$ sulfide deposits because of different partition coefficients of Re and Os between silicate magmas and sulfide melts and between monosulfide solid solution (MSS) and sulfide melts (Brenan 2008). For example, Walker et al. (1994) obtained Re-Os ages of $245.7 \pm 0.6$ and $247.0 \pm$ 3.8 Ma, respectively, for the Noril'sk I Talnakh and Kharaelakh intrusions in Siberia. These two ages are similar to zircon U-Pb ages of $248 \pm 4$ (Campbell et al. 1992) and $251.2 \pm 0.3 \mathrm{Ma}$ (Kamo et al. 1996). Sulfides of komatiitehosted magmatic sulfide deposits in Kambalda have a Re-Os age of $2,706 \pm 36 \mathrm{Ma}$, which is the same within error of zircon $\mathrm{U}-\mathrm{Pb}$ ages of $2,703 \pm 4$ and $2,709 \pm 6 \mathrm{Ma}$ (Foster et al. 1996 and reference therein).

However, in other cases, the Re-Os isotope isochron ages of magmatic sulfide $\mathrm{Ni}-\mathrm{Cu}$ deposits are different from zircon $\mathrm{U}-\mathrm{Pb}$ ages of the host intrusions. Examples include the Voisey's Bay sulfide deposit in Canada, where the Re-Os ages (988-1,302 Ma; Lambert et al. 2000) are younger than the zircon $\mathrm{U}-\mathrm{Pb}$ ages (1,332.7 $\pm 1.0 \mathrm{Ma}$; Amelin et al. 1999). 
The Jinchuan deposit in NW China has zircon and baddeleyite U-Pb ages of $\sim 830 \mathrm{Ma}$ ( $\mathrm{Li}$ et al. 2004), but Re-Os ages range from 833 to $1,117 \mathrm{Ma}$ (Yang et al. 2005; 2008).

Because mantle and crust have different Os isotopic compositions, $\mathrm{Re}-\mathrm{Os}$ isotopic systematics of mantlederived magma are highly sensitive to crustal contamination (Walker et al. 1991; Shirey and Walker 1998). Many magmatic sulfide deposits have been interpreted to have involved crustal contamination (Naldrett 2004; Keays and Lightfoot 2010). The Os isotopic composition of sulfide-bearing mafic intrusions can be modified by contributions of crust with markedly different and potentially variable Re/Os ratios. In this paper, we present Re-Os isotope data for the Kalatongke $\mathrm{Cu}-\mathrm{Ni}$ sulfide deposit in Xinjiang, NW China. Using this deposit as an example, we discuss the causes of the decoupling of Re-Os and zircon U$\mathrm{Pb}$ ages and examine the implications of variable Os isotope compositions for the genesis of sulfide-bearing mafic intrusions.

\section{Geological background}

The Central Asian Orogenic Belt (CAOB), the largest Phanerozoic accretionary belt in the world, extends from the Urals in the west to the Pacific Ocean in the east and is bounded by the Siberia Craton to the north and the Tarim and North China Cratons to the south (Sengör et al. 1993) (Fig. 1a). Extensive Permian magmatism formed voluminous basalts and mafic-ultramafic intrusions in the Tarim Basin and surrounding regions of the CAOB. These rocks, which are thought to have been derived from a mantle plume, form the Tarim large igneous province (Zhou et al. 2004, 2009; Mao et al. 2008; Pirajno et al. 2008).

There are numerous Permian mafic intrusions, including the Kalatongke intrusion, in the NW-SE trending PerkinErtai terrane of the Paleozoic Altay orogenic belt in the CAOB (Windley et al. 2002). They are distributed along the Irtysh River, where they are hosted in sandstones, argillaceous slates, volcanic breccias, and tuffs of the Carboniferous Nanmingshui Formation.

There are 11 segments of the Kalatongke intrusion. The Y1 segment, the largest exposed body, is $695 \mathrm{~m}$ long and up to $270 \mathrm{~m}$ wide. The $\mathrm{Y} 2$ and $\mathrm{Y} 3$ segments are unexposed and occur to the southeast of the Y1 segment. There are six weakly mineralized segments to the east of the $\mathrm{Y} 1$ intrusion (Fig. 1b). All of these intrusions have similar lithologies and consist from the base upward of biotite-hornblende gabbro, olivine norite and troctolite, hornblende norite and biotite diorite. Sulfide ores are only hosted in the olivine norite and troctolite. The Y1, Y2, and Y3 segments contain significant magmatic sulfide ores with 420,000 tons $\mathrm{Cu}$ and 250,000 tons $\mathrm{Ni}$ at grades of $1.3 \% \mathrm{Cu}$ and $0.8 \% \mathrm{Ni}$ (Liu et al. 2005), whereas the other six segments (Y4-9) are weakly mineralized. More than 50 vol. $\%$ of the Y1 segment contains sulfide ores, but only the basal parts ( 10 vol.\%) of the Y2 and Y3 segments are mineralized (Fig. 1c).

The barren norite, including olivine norite and hornblende norite, consists of $\sim 40$ modal $\%$ plagioclase, $10-20$ modal $\%$ olivine, and $\sim 30$ modal $\%$ orthopyroxene, with smaller amounts of clinopyroxene, hornblende, and biotite. Accessory minerals include magnetite, $\mathrm{Cr}$ spinel, and ilmenite. The hornblende norite contains about 10 modal $\%$ amphibole. Olivine is often rimmed by orthopyroxene, which in turn is rimmed by hornblende and biotite. Olivine grains are euhedral to subhedral, whereas orthopyroxene, clinopyroxene, hornblende, and biotite grains are subhedral to anhedral. Textural relationships indicate the following crystallization sequence: $\mathrm{Cr}$ spinel $\rightarrow$ olivine $\rightarrow$ orthopyroxene $\rightarrow$ plagioclase + clinopyroxene $\rightarrow$ hornblende $\rightarrow$ biotite. The norite has been dated using SHRIMP zircon $\mathrm{U}-\mathrm{Pb}$ method at $287 \pm 5 \mathrm{Ma}$ [mean square weighted deviation $(\mathrm{MSWD})=0.34$ ] (Han et al. 2004).

There are disseminated and massive $\mathrm{Ni}-\mathrm{Cu}$ and massive $\mathrm{Cu}$-rich sulfide ores in Kalatongke (Fig. 2). Disseminated $\mathrm{Ni}-\mathrm{Cu}$ sulfide ores are hosted in olivine norite and troctolite and occur in all three segments, whereas massive $\mathrm{Ni}-\mathrm{Cu}$ sulfide ores occur only in the $\mathrm{Y} 1$ and $\mathrm{Y} 2$ segments and their adjacent country rocks. In the $\mathrm{Y} 1$ segment, massive $\mathrm{Ni}-\mathrm{Cu}$ sulfide ores are in sharp contact with disseminated sulfide ores, whereas massive $\mathrm{Cu}$-rich sulfide ores occur as veins in the norite in the lower part of the intrusion. Massive $\mathrm{Cu}$-rich sulfide ores also occur as veinlets in the massive $\mathrm{Ni}-\mathrm{Cu}$ sulfide ores.

The disseminated sulfide ores, (i.e., mineralized norite and troctolite), are composed of 10-50 modal\% sulfide minerals (pyrrhotite, chalcopyrite, and pentlandite), and 50-90 modal\% silicate minerals (plagioclase, olivine, bronzite, hornblende, and biotite; Fig. 2a, b). Massive Ni-Cu sulfide ores consist mainly of pyrrhotite, chalcopyrite, and pentlandite with minor olivine, plagioclase, and hornblende (Fig. 2c). Massive Cu-rich sulfide ores are mostly composed of chalcopyrite with minor pentlandite, pyrrhotite, and silicate minerals (Fig. 2d).

\section{Analytical methods}

Sample preparation and inductively coupled plasma mass spectrometry (ICP-MS) measurements were performed in the National Research Center of Geoanalysis (NRCG), Chinese Academy of Geological Sciences, Beijing. Re and Os concentrations were determined by isotope dilution. ${ }^{185} \mathrm{Re}$ and ${ }^{190}$ Os spikes from Oak Ridge National Laboratory, USA were calibrated at the NRCG. Detailed procedures for sample preparation are available in Du et al. $(2001,2004)$ and 


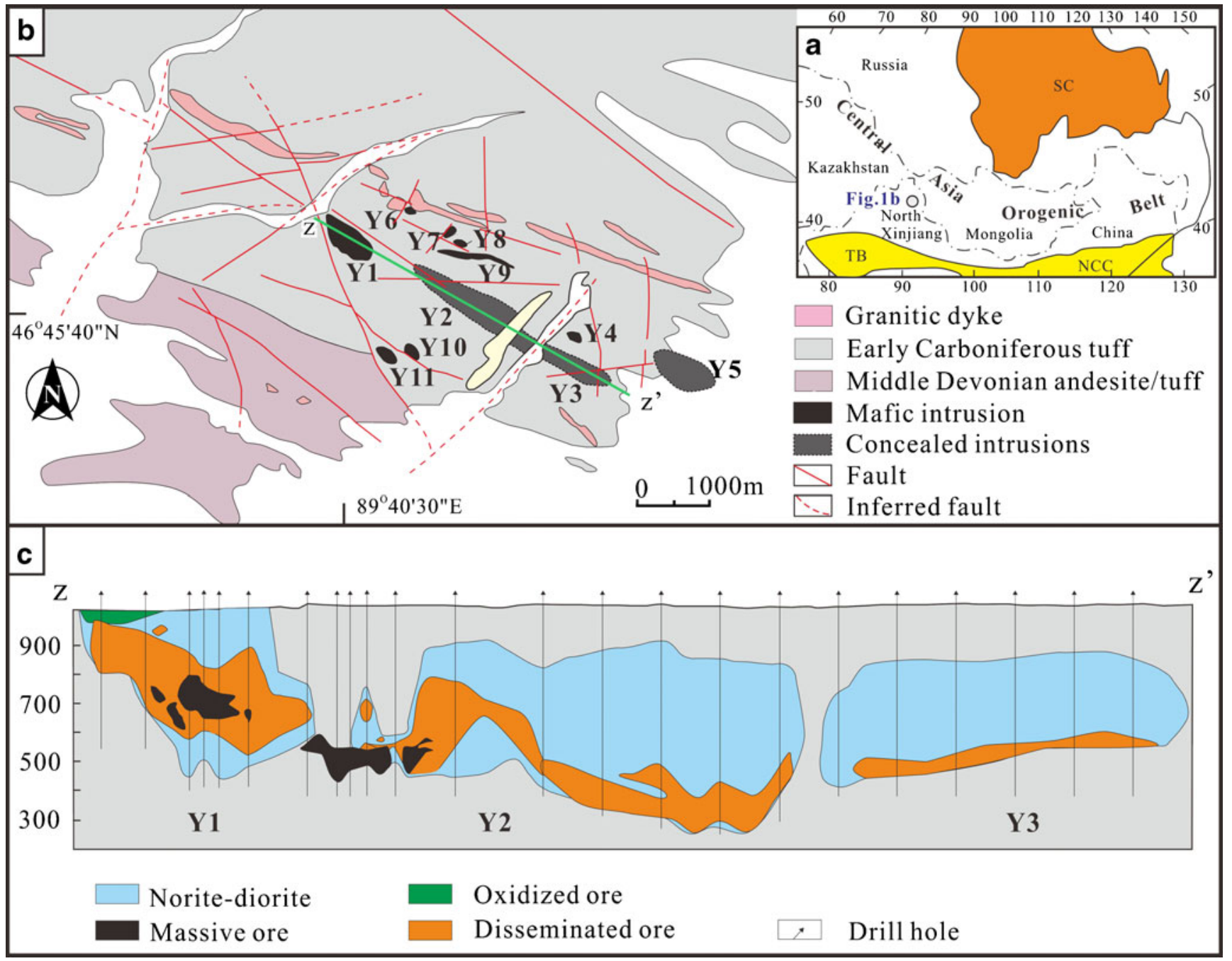

Fig. 1 a Location of the study area in the CAOB (modified from Sengör et al. 1993). b Simplified geological map of the Kalatongke mine area, North Xinjiang, China (modified from Wang and Zhao
1991). c Cross section of the Y1, Y2, and Y3 segments of Kalatongke (modified from Wang and Zhao 1991). TB Tarim Block, SC Siberian Craton, and NCC North China Craton
Yang et al. (2008). Re and Os concentrations were measured with a Thermo X7 Quadrupole ICP-MS. Because of the low concentration of Os, signal intensities of the Os isotopes were measured with a Pt screen. The signal intensities of both Re and Os in this mode are $\sim 200,000 \mathrm{cps} / \mathrm{ppb} .{ }^{190} \mathrm{Os}$ intensity was used to correct for the interference of ${ }^{187} \mathrm{Os}$ on ${ }^{187} \mathrm{Re}$, and ${ }^{185} \mathrm{Re}$ intensity was used to correct for Re on Os. The total procedural blanks were about $5 \mathrm{pg}$ for Re and 1 to $0.2 \mathrm{pg}$ for Os based on blank runs analyzed together with the samples. ${ }^{187} \mathrm{Os} /{ }^{188} \mathrm{Os}$ ratios of the blank are 0.25 based on routine measurements. The standard material, GBW04436 (JDC, a molybdenite from the Jinduicheng deposit, China), was used to monitor the accuracy of the measurements. Re and Os contents and Re-Os ages of the JDC molybdenite determined during the course of this work are 17,340 \pm $40 \mathrm{ppb}, 25.25 \pm 0.07 \mathrm{ppb}$, and $138.9 \pm 0.5 \mathrm{Ma}(n=17)$, respectively, which coincide within uncertainties with the reference values $(\mathrm{Re}=17,390 \pm 320 \mathrm{ppb}, \mathrm{Os}=25.5 \pm 0.6 \mathrm{ppb}$, and $t=139.6 \pm 3.8 \mathrm{Ma}$; Du et al. 2004).

\section{Results}

Two tuff samples from the country rocks of the Nanmingshui Formation were taken from drill core 7501 that penetrated the Y3 segment. They contain 1.07-2.00 ppb Re, and 0.015-0.027 ppb common Os, with ${ }^{187} \mathrm{Re}^{188} \mathrm{Os}$ ratios of $339-361$ and ${ }^{187} \mathrm{Os} /{ }^{188}$ Os ratios of 2.122-2.339. When calculated to an age of $287 \mathrm{Ma}$ (Han et al. 2004), $\gamma_{\text {Os }}$ values for the two samples are +295 and +384 .

Nine samples from the Kalatongke sulfide-bearing segment were analyzed for $\mathrm{Re}-\mathrm{Os}$ isotopic compositions (Table 1). A barren norite sample from drill core 7501 has $1.89 \mathrm{ppb} \mathrm{Re}$, and $0.181 \mathrm{ppb}$ common Os with a 
Fig. 2 Photomicrographs of $\mathbf{a}-\mathbf{b}$ disseminated sulfide ores, $\mathbf{c}$ massive $\mathrm{Ni}-\mathrm{Cu}$ sulfide ore, and d massive $\mathrm{Cu}$-rich sulfide ore from the Y1 segment. $\mathrm{Ol}$ olivine, $O p x$ orthopyroxene, Horn hornblende, $B i$ biotite, $P l$ plagioclase, $C c p$ chalcopyrite, $P o$ pyrrhotite, $P n$ pentlandite
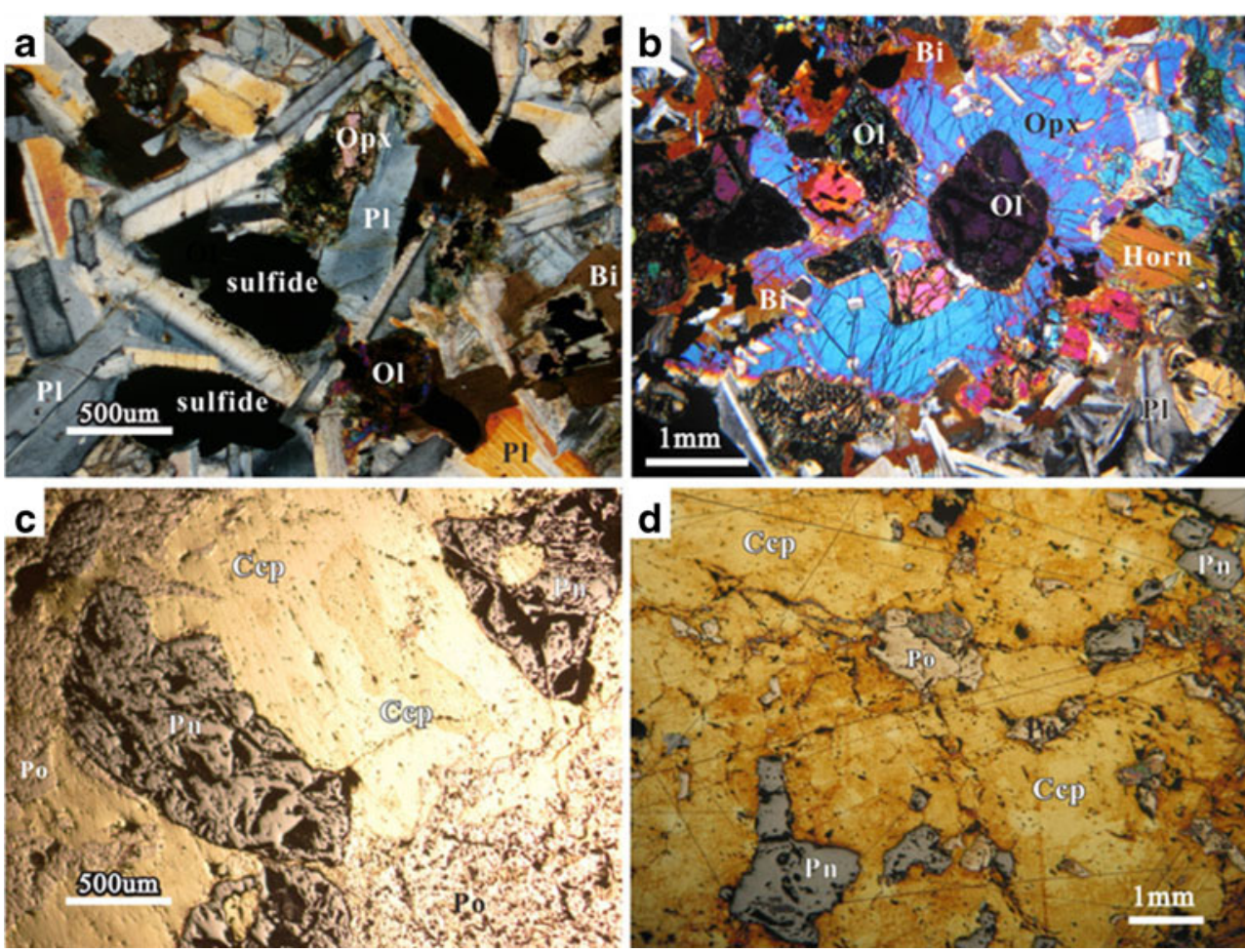

${ }^{187} \mathrm{Re} /{ }^{188} \mathrm{Os}$ ratio of 50.4 and ${ }^{187} \mathrm{Os} /{ }^{188} \mathrm{Os}$ ratio of 0.467. The calculated $\gamma_{\text {Os(287Ma) }}$ value is +79 .

Four disseminated sulfide ore samples (one from drill core 7501 of the Y3 segment and three from the underground adit in the Y1 segment) contain 2.98 to $6.23 \mathrm{ppb}$ Re and 0.133 to $0.787 \mathrm{ppb}$ common Os, with ${ }^{187} \mathrm{Re} /{ }^{188} \mathrm{Os}$ ratios ranging from 29.6 to 125.3 and ${ }^{187} \mathrm{Os} /{ }^{188} \mathrm{Os}$ ratios from 0.415 to 0.975 . Their calculated $\gamma_{\text {Os(287Ma) }}$ values range from +117 to +198 .

Two massive $\mathrm{Ni}-\mathrm{Cu}$ ore samples from the $\mathrm{Y} 1$ segment have 10.4 and $27.9 \mathrm{ppb} \mathrm{Re}$, and 0.241 and $1.10 \mathrm{ppb}$ common Os, ${ }^{187} \mathrm{Re} /{ }^{188} \mathrm{Os}$ ratios of 122.1 and 208.0 and

Table 1 Re and Os concentrations and isotopic compositions for the Kalatongke deposit

\begin{tabular}{|c|c|c|c|c|c|c|c|c|c|c|c|}
\hline Samples & $\operatorname{Re}(p p b)$ & $2 \sigma$ & $\mathrm{Os}^{\mathrm{a}}(\mathrm{ppb})$ & $2 \sigma$ & ${ }^{187} \mathrm{Os}(\mathrm{ppb})$ & $2 \sigma$ & ${ }^{187} \mathrm{Re} /{ }^{188} \mathrm{Os}$ & $2 \sigma$ & ${ }^{187} \mathrm{Os} /{ }^{188} \mathrm{Os}$ & $2 \sigma$ & $\gamma_{\mathrm{Os}}$ \\
\hline \multicolumn{12}{|c|}{ Tuff (country rock) } \\
\hline KTG72 & 2.004 & 0.015 & 0.0268 & 0.0002 & 0.0082 & 0.0001 & 361.2 & 3.8 & 2.339 & 0.016 & 384 \\
\hline KTG134 & 1.070 & 0.011 & 0.0152 & 0.0001 & 0.0042 & 0.0001 & 339.3 & 4.6 & 2.122 & 0.016 & 295 \\
\hline \multicolumn{12}{|l|}{ Barren norite } \\
\hline KTG128-Y3 & 1.894 & 0.017 & 0.1814 & 0.0014 & 0.0110 & 0.0001 & 50.4 & 0.61 & 0.467 & 0.003 & 79 \\
\hline \multicolumn{12}{|c|}{ Disseminated sulfide ores } \\
\hline KTG131-Y3 & 4.832 & 0.039 & 0.7873 & 0.0071 & 0.0425 & 0.0004 & 29.6 & 0.36 & 0.415 & 0.003 & 117 \\
\hline KTG135-Y1 & 4.598 & 0.037 & 0.1773 & 0.0014 & 0.0225 & 0.0002 & 125.3 & 1.4 & 0.975 & 0.006 & 198 \\
\hline KTG136-Y1 & 2.982 & 0.027 & 0.1332 & 0.0010 & 0.0151 & 0.0001 & 108.2 & 1.3 & 0.871 & 0.003 & 180 \\
\hline KTG146-Y1 & 6.235 & 0.066 & 0.3299 & 0.0028 & 0.0326 & 0.0003 & 91.3 & 1.25 & 0.759 & 0.005 & 156 \\
\hline \multicolumn{12}{|c|}{ Massive $\mathrm{Ni}-\mathrm{Cu}$ sulfide ores } \\
\hline KTG141-Y1 & 10.37 & 0.161 & 0.2408 & 0.0025 & 0.0375 & 0.0005 & 208.0 & 3.9 & 1.196 & 0.015 & 59 \\
\hline KTG147-Y1 & 27.90 & 0.256 & 1.1036 & 0.0080 & 0.1175 & 0.0010 & 122.1 & 1.4 & 0.818 & 0.004 & 85 \\
\hline \multicolumn{12}{|c|}{ Massive $\mathrm{Cu}$-rich sulfide ores } \\
\hline KTG162-Y1 & 1.551 & 0.015 & 0.1270 & 0.0020 & 0.0101 & 0.0003 & 59.0 & 1.09 & 0.609 & 0.022 & 160 \\
\hline KTG163-Y1 & 1.674 & 0.016 & 0.1330 & 0.0021 & 0.0103 & 0.0002 & 60.8 & 1.1 & 0.595 & 0.012 & 141 \\
\hline
\end{tabular}

The parameters used to calculate $\gamma_{\text {Os }}$ are $\lambda_{\mathrm{Re}}=1.666 \times 10^{-11}$ year, $\left({ }^{187} \mathrm{Re} /{ }^{188} \mathrm{Os}\right)_{\text {chond }}=0.40186$ and $\left({ }^{187} \mathrm{Os} /{ }^{188} \mathrm{Os}\right)_{\text {chond, } 0}=0.1270(\mathrm{Shirey}$ and Walker 1998). The age of calibration is $287 \mathrm{Ma}$ (Han et al. 2004)

${ }^{\mathrm{a}}$ Common Os 
${ }^{187} \mathrm{Os} /{ }^{188}$ Os ratios of 0.818 and 1.196 . Two massive $\mathrm{Cu}$-rich ore samples from the same segment have Re from 1.55 to $1.67 \mathrm{ppb}$ and common Os from 0.127 to $0.133 \mathrm{ppb}$, with ${ }^{187} \mathrm{Re} /{ }^{188} \mathrm{Os}$ ratios of 58.0 and 60.8 , and ${ }^{187} \mathrm{Os} /{ }^{188} \mathrm{Os}$ ratios of 0.595 and $0.609 . \gamma_{\mathrm{Os}(287 \mathrm{Ma})}$ values of the massive $\mathrm{Ni}-\mathrm{Cu}$ and $\mathrm{Cu}$-rich sulfide ores range from +59 to +85 and +141 to +160 , respectively.

Barren norite, disseminated sulfide ores, massive $\mathrm{Ni}-\mathrm{Cu}$, and massive $\mathrm{Cu}$-rich sulfide ores from Kalatongke have variable Os isotopic compositions (Table 1 and Fig. 3). Han et al. (2007) and Zhang et al. (2008) reported Os isotope data for disseminated and massive sulfide ores, respectively. Massive sulfide ores from Zhang et al. (2008) and this study have a limited variation of $\gamma_{O s}$ values (Fig. 3a). Disseminated sulfide ores from Han et al. (2007) and this study plot between the norite and country rocks (Fig. 3a) and form a trend with a positive correlation between $\gamma_{\text {Os }}$ values and ${ }^{187} \mathrm{Re} /{ }^{188}$ Os ratios, different from the massive sulfide ores with relatively consistent Os isotope compositions.
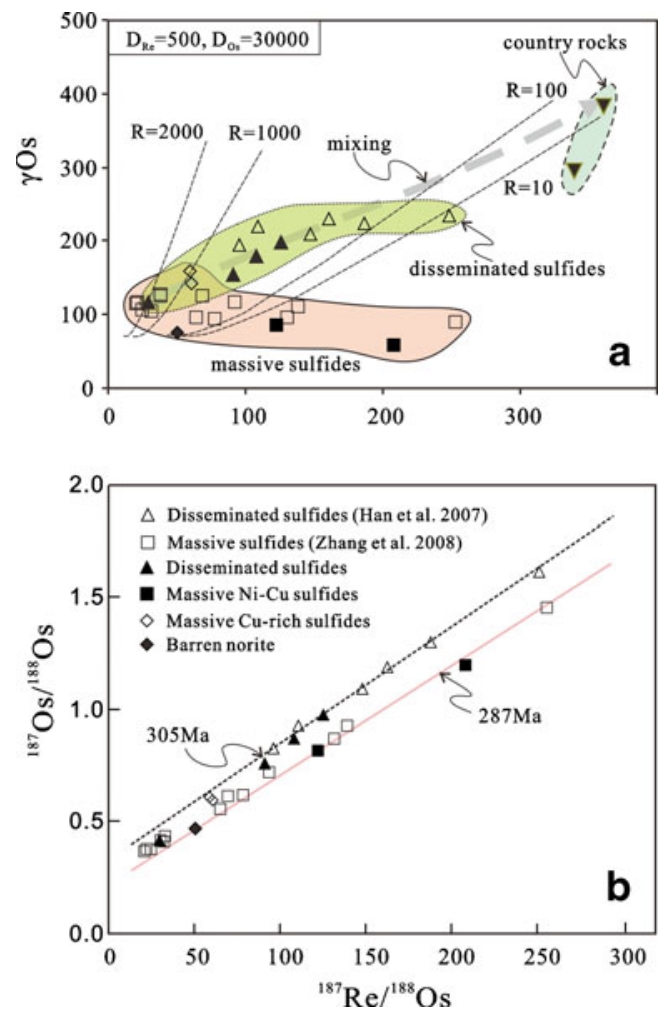

Fig. 3 a Plot of ${ }^{187} \mathrm{Re} /{ }^{188} \mathrm{Os}$ ratios vs $\gamma_{\mathrm{Os}}$ values and b plot of ${ }^{187} \mathrm{Re} /{ }^{188} \mathrm{Os}$ ratios vs ${ }^{187} \mathrm{Os} /{ }^{188} \mathrm{Os}$ ratios for different sulfide ores and silicate rocks from the Kalatongke mafic intrusion. $R$ is the ratio of the mass of silicate magma to the mass of sulfide and is calculated using the following formula: $C_{\mathrm{i}}=C_{0} \times \mathrm{D} \times\left(R_{\mathrm{i}}+1\right) /\left(R_{\mathrm{i}}+D\right)$, where $C_{\mathrm{i}}$ is the final concentration of metal $i$ in the sulfide melt, $C_{0}$ is the metal concentration in the original silicate melt, $D$ is the sulfide/silicate melt partition coefficient (Campbell and Naldrett 1979). $D_{\mathrm{Re}}=500$ and $D_{\mathrm{Os}}=30,000$ were used in this study

\section{Discussion}

Os isotope compositions in the Kalatongke intrusion

The heterogeneous Os isotope composition in Kalatongke yielded highly variable $\mathrm{Re}-\mathrm{Os}$ isochron ages. The four massive sulfide samples yielded a poor Re-Os isochron age of $239 \pm 51 \mathrm{Ma}(\mathrm{MSWD}=12)$, and four disseminated sulfide ores yielded a $\mathrm{Re}-\mathrm{Os}$ age of $349 \pm 34 \mathrm{Ma}$ $(\mathrm{MSWD}=5.0)$. Previous studies reported Re-Os isochron ages of $282.5 \pm 4.8 \mathrm{Ma}(\mathrm{MSWD}=1.5)$ for the Y1 segment, $290.2 \pm 6.9 \mathrm{Ma}(\mathrm{MSWD}=1.02)$ for the Y2 segment (Zhang et al. 2008), and $305 \pm 15 \mathrm{Ma}(\mathrm{MSWD}=2.1$ ) (Han et al. 2007) for massive and disseminated sulfide ores, which are within errors of our Re-Os ages. When all data are plotted in a ${ }^{187} \mathrm{Re} /{ }^{188} \mathrm{Os}^{187} \mathrm{Os} /{ }^{188}$ Os diagram (Fig. 3b), the disseminated sulfides plot roughly on the $305-\mathrm{Ma}$ isochron line determined by Han et al. (2007) for disseminated ores, whereas massive sulfide ores plot along the isochron line for norites ( $287 \mathrm{Ma}$; Han et al. (2004)). The barren norite analyzed in our study also plots on this 287-Ma line (Fig. 3b). Thus, the disseminated sulfide ores are at least $20 \mathrm{Ma}$ older than the massive sulfide ores. The difference between Re-Os ages emphasizes the variability of the Os isotope composition in the sulfide-bearing mafic intrusions of Kalatongke.

Heterogeneous Os isotope compositions of mafic intrusions are known in the literature, but their origin is still a matter of debate. Heterogeneous Os isotope compositions of MORB or OIB are commonly attributed to heterogeneous mantle sources (Walker et al. 1999; Gannoun et al. 2004). Heterogeneous Os isotope composition in the Sudbury complex, Canada was explained as having been derived from different sources (Walker et al. 1991) or mixing between mantle-derived magmas and crustal rocks (Cohen et al. 2000). Walker et al. (1994) attributed heterogeneous Os isotope compositions of the sulfide ore-bearing intrusions in the Noril'sk region, Russia to interaction between mantlederived magmas and various lithospheric components. Variable Os isotope composition was also thought to be produced by different diffusion rates of Os or later disturbances (Cohen et al. 2000; Lambert et al. 2000; Yang et al. 2008). However, Re-Os isotope variations of massive sulfide ores from Kalatongke cannot be explained by later disturbances or different diffusion rates because they have Os isotope compositions similar to the barren norites, but different from the disseminated sulfide ores.

Os can easily diffuse between sulfide minerals in massive sulfide ores but not between the silicate minerals and sulfide minerals (Yang et al. 2008). In Kalatongke, the difference of Os isotope compositions between $\mathrm{Cu}$-rich massive sulfide ores and $\mathrm{Ni}-\mathrm{Cu}$ massive sulfide ores cannot be caused by Os diffusion. On the other hand, if the Os composition was 
homogeneous in the parental mafic magmas, massive and disseminated sulfide ores produced from these magmas should have achieved Os equilibrium instead of heterogeneous Os composition in different sulfide ores. Systematic variation of Re-Os isotopes in Kalatongke also cannot be explained by later disturbances or hydrothermal alteration. Later disturbances may yield younger Re-Os ages than zircon U-Pb ages (Cohen et al. 2000; Lambert et al. 2000), but Re-Os ages of the Kalatongke ores are either older or younger than the zircon $\mathrm{U}-\mathrm{Pb}$ ages. Hydrothermal alteration can also be ruled out because the host intrusion and sulfide ores in Kalatongke have undergone little or no hydrothermal alteration and the samples selected for analyses are fresh.

Interaction between mantle-derived magmas and various lithospheric components, particularly crust, has been recognized in many sulfide-bearing mafic intrusions (e.g., Walker et al. 1994). Sulfide mineralization in mafic intrusions is generally thought to be caused by crustal contamination and fractional crystallization (Naldrett 2004), and it has been argued that contamination by S-rich crustal materials is required for the genesis of magmatic $\mathrm{Cu}-\mathrm{Ni}$ sulfide deposits (e.g., Keays and Lightfoot 2010). Therefore, it is possible that Os isotope composition heterogeneities in sulfidebearing mafic magma systems may be related to crustal contamination and sulfide segregation under different $R$ factors. $\gamma_{\text {Os }}$ values and Re/Os ratios of sulfides are similar to those of the contaminant at low $R$ factor, whereas $\gamma_{\mathrm{Os}}$ values and Re/Os ratios of sulfides approach those of the magma at high $R$ factor (Lesher and Burnham 2001). However, modeling of the $R$ factor suggests that sulfides in Kalatongke were not formed with a single $R$ factor process (Fig. 3a). In sulfide-bearing mafic magma systems, most Re and Os are hosted in sulfides, which may have formed at different stages during the magma evolution and thus record different Os isotope compositions. In Kalatongke, both the massive sulfide ores and barren norite have similar Re/Os ratios and $\gamma_{\text {Os }}$ values and are thought to be have derived from the same pulse of sulfide-bearing magma. On the other hand, the disseminated sulfide ores have higher $\gamma_{\mathrm{Os}}$ values and formed from a different pulse of magma.

Formation of the massive sulfide ore and barren norite

Both $\mathrm{Ni}-\mathrm{Cu}$ and $\mathrm{Cu}$-rich massive sulfide ores have a limited variation of Os isotope compositions, similar to those of the barren norite, suggesting that large amounts of sulfide melts were segregated from silicate magmas that formed the norite and concentrated possibly at the bottom of the magma chamber at high temperature and low viscosity. Crystallization of MSS from massive sulfide melts may produce $\mathrm{Ni}$ rich and $\mathrm{Cu}$-rich sulfide ores (e.g., Ebel and Naldrett 1996), but Os isotope compositions should remain the same in a closed system. In Kalatongke, the massive sulfide ores have nearly homogeneous $\gamma_{\mathrm{Os}}$ values but variable Re/Os ratios which may be due to either fractionation of sulfide melts or interaction of such melts with silicate magmas because Os is significantly more compatible than Re in sulfides than in silicate magmas (Brenan 2002, 2008).

Formation of the disseminated sulfide ore

Os isotope compositions and $\mathrm{Re} / \mathrm{Os}$ ratios of disseminated sulfide ores from Kalatongke correlate positively and form a trend towards the hosting country rocks (Fig. 3a). The disseminated sulfide ores contain more radiogenic Os than both the massive $\mathrm{Ni}-\mathrm{Cu}$ and $\mathrm{Cu}$-rich sulfide ores. Because the immediate country rocks in Kalatongke have the highest radiogenic Os compositions, we suggest that the disseminated sulfide ores were formed from highly contaminated melts. As temperature decreases, the crystal content and viscosity of silicate magmas increase, leading to more heterogeneous contamination. Variable Os isotope compositions for disseminated sulfides ores can be explained by variable abundances of crustal Os. If we assume that the samples with the least radiogenic Os have the minimum contamination, modeling suggests that the highest degree of contamination was more than 50\% (Fig. 3a). Experimental data have confirmed that sulfur and Os from decomposing crustal sulfides can be transferred into silicate magmas as part of the vapor phase (Baker et al. 1998). Thus, Os in crustal sulfides can be easily added into the mafic magmas and modify the Os composition of the magma. Sulfide droplets cannot be separated and segregated as sulfide melts to form massive sulfide orebodies under high viscosity. These individual sulfide droplets in the silicate magmas would have been trapped to form disseminated sulfide ores and record the additional contamination history during magma evolution. Thus, disseminated sulfide ores would have different radiogenic Os compositions because of different degrees of crustal contamination.

Implications for Re-Os dating and sulfide formation

Mafic intrusions that crystallized from PGE-rich magmas, such as the Noril'sk I and Talnakh-Kharaelahk intrusions, Siberia and the Kambalda deposit in Australia, have similar $\mathrm{Re}-\mathrm{Os}$ and zircon $\mathrm{U}-\mathrm{Pb}$ ages. In these deposits, the systems have high Os contents ( $>10 \mathrm{ppb})$ and low Re/Os ratios, such that their Re-Os compositions are not easily altered by crustal contamination.

The Kalatongke intrusion are depleted in PGE relative to $\mathrm{Ni}$ and $\mathrm{Cu}$ and are thought to have undergone sulfide removal (Song and $\mathrm{Li}$ 2009). Os isotope compositions of mafic magmas that are depleted in PGE, particularly Os, due to sulfide removal or fractional crystallization of olivine 
and/or chromite (Crocket 2002), can be easily modified by crustal contamination (Shirey and Walker 1998). If such a contamination results in heterogeneous Os isotope compositions in the mafic intrusions, Re-Os dating of these sulfides and intrusions cannot yield the true formation age.

Os isotopes of sulfide melts can reach equilibrium under high temperature because of their high diffusion rate (Brenan et al. 2000). Therefore, MSS grains commonly have Os isotope compositions similar to those of the co-existing $\mathrm{Cu}$-rich sulfide melts. In Kalatongke, there are only small differences in $\gamma_{\mathrm{Os}}$ between massive $\mathrm{Ni}-\mathrm{Cu}$ and $\mathrm{Cu}$-rich sulfide ores, yielding only small differences between the $\mathrm{Re}-\mathrm{Os}$ isochron and zircon $\mathrm{U}-\mathrm{Pb}$ ages (e.g., Zhang et al. 2008; this study).

The formation of disseminated sulfide ores typically involves assimilation and fractional crystallization (AFC). Assimilation of S-rich country rocks has been proposed to explain the origin of magmatic sulfide ore deposits (Lesher and Burnham 2001), and selective crustal contamination has been invoked to explain the behavior of different isotope systems during the interaction between mantle-derived magmas and crustal rocks (Watson 1982; Walker et al. 1994; Ripley et al. 1999, 2001; Lambert et al. 2000). In an AFC process, if the systems are variably contaminated, the Re-Os data will plot around the mixing lines between parental magmas and contaminants and form "pseudoisochrons" (DePaolo 1981). In sulfide-bearing mafic intrusions, a different degree of contamination can be recorded by the disseminated sulfide (Yang et al. 2008), such that the ReOs isochron produced by the disseminated sulfide ores in Kalatongke is a pseudoisochron that does not have geological significance. That is why the disseminated sulfide ores have variable Re-Os ages and are not useful for precise geochronology.

Both massive and disseminated sulfide ores are generally considered to have formed at the same stage (Barnes and Lightfoot 2005), which is not supported by this study. Identification of the timing of sulfide segregation is difficult, but the Os isotope composition can be used to trace multiple pulses of sulfide-bearing magmas and/or crustal contamination recorded in sulfides and thus aid in the study of sulfide-forming processes in sulfide-bearing mafic intrusions.

\section{Conclusions}

Massive sulfide ores and barren norite in the Kalatongke intrusion have $\mathrm{Re}-\mathrm{Os}$ isotope compositions different from those of the disseminated sulfide ores, reflecting variable amounts of crustal contamination. Heterogeneous Os isotope compositions may record the magma evolution, but are not suitable for dating $\mathrm{Cu}-\mathrm{Ni}$ sulfide mineralized intrusions. Massive sulfide ores, particularly massive Ni-rich sulfide ores, may have homogeneous Os isotope compositions and $\mathrm{Re}-\mathrm{Os}$ ages closer to the true age of mineralization. Os isotope compositions of both massive $\mathrm{Cu}$-rich sulfide ores and disseminated sulfide ores may have undergone additional modification and are problematic for dating.

Acknowledgments This study was supported by grants from the Research Grants Council of Hong Kong (HKU7058/08P), Vale INCO, and a Opening Foundation of State Key Laboratory of Ore Deposit Geochemistry, Institute of Geochemistry, CAS (200802). We thank Xinsheng Dang, Yong Wang, Bin Wang, Caineng Tu, and Junhui Xie of the Kalatongke Mine for sharing their knowledge about the local geology. Yongsheng He of Geological Team No.4 of Xinjiang was a very capable field assistant. Ms. Andao Du and Mr. Chao Li provided assistance with the lab work. An earlier draft of this paper was improved by the thoughtful comments and suggestions from Paul Robinson, Shenghong Yang, and Simon Leung. Edward Ripley and Bernd Lehmann are thanked for providing constructive reviews and editorial comments.

Open Access This article is distributed under the terms of the Creative Commons Attribution License which permits any use, distribution, and reproduction in any medium, provided the original author(s) and the source are credited.

\section{References}

Amelin Y, Li CS, Naldrett AJ (1999) Geochronology of the Voisey's Bay intrusion, Labrador, Canada, by precise $\mathrm{U}-\mathrm{Pb}$ dating of coexisting baddeleyite, zircon, and apatite. Lithos 47:33-51

Baker DR, Barnes SJ, Bernier F, Simon G (1998) Vapour transport of S into mafic melts. GAC/MAC Annual Meeting Program with Abstracts volume 23, A7

Barnes SJ and Lightfoot PC (2005) Formation of magmatic nickelsulfide ore deposits and processses affecting their copper and platinum-group element contents. In: Hedenquist JW, Thompson JFH, Goldfarb RJ and Richards JP (eds) Econ Geol 100th Anniversary Volume, pp. 179-213

Brenan JM (2002) Re-Os fractionation in magmatic sulfide melt by monosulfide solid solution. Earth Planet Sci Lett 199:257-268

Brenan JM (2008) Re-Os fractionation by sulfide melt-silicate melt partitioning: a new spin. Chem Geol 248:140-165

Brenan JM, Cherniak DJ, Rose LA (2000) Diffusion of osmium in pyrrhotite and pyrite: implications for closure of the Re-Os isotopic system. Earth Planet Sci Lett 180:399-413

Campbell IH, Naldrett AJ (1979) The influence of silicate:sulfide ratios on the geochemistry of magmatic sulfides. Econ Geol 74:15031506

Campbell IH, Czamanske GK, Fedorenko VA, Hill RI, Stepanov V, Kunilov VE (1992) Synchronism of the Siberian traps and the Permian-Triassic boundary. Science 258:1760-1763

Cohen AS, Burnham OM, Hawkesworth CJ, Lightfoot PC (2000) Preemplacement Re-Os ages from ultramafic inclusions in the sublayer of the Sudbury Igneous Complex, Ontario. Chem Geol $165: 37-46$

Crocket JH (2002) Platinum-group element geochemistry of mafic and ultramafic rocks. In: Cabri LJ (ed) The geology, geochemistry, mineralogy and mineral beneficiation of platinum-group elements. Canadian Institute of Mining Metallurgy and Petroleum 54:177210, Special volume 
DePaolo DJ (1981) Trace element and isotopic effects of the combined wallrock assimilation and fractional crystallization. Earth Planet Sci Lett 53:189-202

Du AD, Zhao DM, Wang SX, Sun DZ, Liu DY (2001) Precise Re-Os dating for molybdenite by ID-NTIMS with Carius Tube sample preparation. Rock Miner Anal 20:247-252 (in Chinese with English abstract)

Du AD, Wu SQ, Sun DZ, Wang SX, Qu WJ, Markey R, Stein H, Morgan J, Malinovskiy D (2004) Preparation and certification of Re-Os dating reference materials: molybdenite HLP and JDC. Geostand Geoanal Res 28:41-52

Ebel DS, Naldrett AJ (1996) Fractional crystallization of sulfide ore liquid at high temperature. Econ Geol 91:607-637

Foster JG, Lambert DD, Frick LR, Maas R (1996) Re-Os isotopic evidence for genesis of Archaean nickel ores from uncontaminated komatiites. Nature 382:703-706

Gannoun A, Burton KW, Thomas LE, Parkison IJ, Calsteren P, van Schiano P (2004) Osmium isotope heterogeneity in the constituent phases of mid-ocean ridge basalts. Science 303:70-72

Han BF, Ji JQ, Song B, Chen LH, Li ZH (2004) SHRIMP zircon U-Pb ages of Kalatongke No. 1 and Huangshandong $\mathrm{Cu}-\mathrm{Ni}$-bearing mafic-ultramafic complexes, North Xinjiang, and geological implications. Chin Sci Bull 49(22):2424-2429

Han CM, Xiao WJ, Zhao GC, Qu WJ, Du AD (2007) Re-Os dating of the Kalatongke $\mathrm{Cu}-\mathrm{Ni}$ sulfide deposit, Altay Shan, NW China, and resulting geodynamic implications. Ore Geol Rev 32:452-468

Kamo SL, Czamanske GK, Krogh TE (1996) A minimum U-Pb age for Siberian flood-basalt volcanism. Geochim Cosmochim Acta 60:3505-3511

Keays RR, Lightfoot PC (2010) Crustal sulfur is required to form magmatic $\mathrm{Ni}-\mathrm{Cu}$ sulfide deposits: evidence from chalcophile element signatures of Siberian and Deccan Traps basalts. Miner Deposita 45:241-257

Lambert DD, Frick LR, Foster JG, Li CS, Naldrett AJ (2000) Re-Os isotope systematics of the Voisey's Bay $\mathrm{Ni}-\mathrm{Cu}-\mathrm{Co}$ magmatic sulfide system, Labrador, Canada: II Implications for parental magma chemistry, ore genesis, and metal redistribution. Econ Geol 95:867-888

Lesher CM, Burnham OM (2001) Multicomponent elemental and isotopic mixing in $\mathrm{Ni}-\mathrm{Cu}-(\mathrm{PGE})$ ores at Kambalda, Western Australia. Can Mineral 39:421-446

Li XH, Su L, Song B, Liu DY (2004) SHRIMP U-Pb zircon age of the Jinchuan ultramafic intrusion and its geological significance. Chin Sci Bull 49:420-422 (in Chinese with English abstract)

Liu DQ, Tang YL, Zhou RH (2005) Copper deposits and nickel deposits in Xinjiang, China. Geological Publishing House, Beijing, p 360, in Chinese

Mao JW, Pirajno F, Zhang ZH, Chai FM, Wu H, Chen SP, Cheng SL, Yang JM, Zhang CQ (2008) $\mathrm{Cu}-\mathrm{Ni}$ sulphide deposits in the Chinese Tianshan and Altay orogens (Xinjiang Autonomous Region): principal characteristics and ore-forming processes. J Asian Earth Sci 32:184-203

Naldrett AJ (2004) Magmatic sulfide deposits: geology, geochemistry and exploration. Springer, Berlin Heidelberg New York, p 728

Pirajno F, Mao JW, Zhang ZC, Zhang ZH, Chai FM (2008) The association of mafic-ultramafic intrusions and A-type magmatism in the Tian Shan and Altay orogens, NW China: implications for geodynamic evolution and potential for the discovery of new ore deposits. J Asian Earth Sci 32:165-183
Ripley EM, Park YR, Li C, Naldrett AJ (1999) Sulfur and oxygen isotopic evidence of country rock contamination in the Voisey's Bay Ni-Cu-Co deposit, Labrador, Canada. Lithos 47:53-68

Ripley EM, Park YR, Lambert DD, Frick LR (2001) Re-Os isotopic variations in carbonaceous pelites hosting the Duluth Complex: implications for metamorphic and metasomatic process associated with mafic magma chambers. Geochim Cosmochim Acta 65:2965-2978

Sengör AMC, Natal'in BA, Burtman US (1993) Evolution of the Altaid Tectonic Collage and Paleozoic Crustal growth in Eurasia. Nature 364:209-304

Shirey SB, Walker RJ (1998) The Re-Os isotope system in cosmochemistry and high-temperature geochemistry. Annual Rev Earth Planet Sci 26:423-500

Song XY, Li XR (2009) Geochemistry of the Kalatongke Ni-Cu(PGE) sulfide deposit, NW China: implications for the formation of magmatic sulfide mineralization in a postcollisional environment. Miner Deposita 44:303-327

Walker RJ, Morgan JW, Naldrett AJ, Li C, Fassett JD (1991) Re-Os isotope systematics of Ni-Cu sulfide ores, Sudbury Igneous Complex, Ontario: evidence for a major crustal component. Earth Planet Sci Lett 105:416-429

Walker RJ, Morgan JW, Horan MF, Czamanske GK, Krogstad EJ, Fedorenko VA, Kunilov VE (1994) Re-Os isotopic evidence for an enriched-mantle source for the Noril'sk-type, ore-bearing intrusions, Siberia. Geochim Cosmochim Acta 58:4179-4197

Walker RJ, Storey M, Kerr AC, Tarney J, Arndt NT (1999) Implications of ${ }^{187} \mathrm{Os}$ isotopic heterogeneities in a mantle plume: evidence from Gorgona Island and Curacao. Geochim Cosmochim Acta 63:713-728

Wang RM, Zhao CL (1991) Karatungk Cu-Ni sulfide No.1 ore deposit in Xinjiang. Geological Publishing House, Beijing, p 391, in Chinese

Watson EB (1982) Basalt contamination by continental crust: some experiments and models. Contrib Mineral Petrol 80:73-87

Windley BF, Kroner A, Guo J, Qu G, Li Y, Zhang C (2002) Neoproterozoic to Paleozoic geology of the Altai Orogen, NW China: new zircon age data and tectonic evolution. J Geol 110:719-737

Yang G, Du AD, Lu JR, Qu WJ, Chen JF (2005) Re-Os (ICP-MS) dating of the massive sulfide ores from the Jinchuan $\mathrm{Ni}-\mathrm{Cu}-\mathrm{PGE}$ deposit. Sci China Ser D Earth Sci 48:1672-1677

Yang SH, Qu WJ, Tian L, Chen JF, Du AD, Yang G (2008) Origin of the inconsistent apparent $\mathrm{Re}-\mathrm{Os}$ age of the Jinchuan $\mathrm{Ni}-\mathrm{Cu}$ sulfide ore deposit, China: post-segregation diffusion of Os. Chem Geol 247:401-418

Zhang ZH, Mao JW, Du AD, Pirajno F, Wang ZL, Chai FM, Zhang ZC, Yang JM (2008) Re-Os dating of two Cu-Ni sulfide deposits in northern Xinjiang, NW China and its geological significance. J Asian Earth Sci 32:204-217

Zhou MF, Lesher CM, Yang Z, Li J, Sun M (2004) Geochemistry and petrogenesis of $270 \mathrm{Ma} \mathrm{Ni-Cu-(PGE)} \mathrm{sulfide-bearing} \mathrm{mafic}$ intrusions in the Huangshan district, Eastern Xinjiang, Northwest China: implications for the tectonic evolution of the Central Asian orogenic Belt. Chem Geol 209:233-257

Zhou MF, Zhao JH, Jiang CY, Gao JF, Wang W, Yang SH (2009) OIB-like, heterogeneous mantle sources of Permian basaltic magmatism in the western Tarim Basin, NW China: implications for a possible Permian large igneous province. Lithos 113:583-594 